Strategy Study

Strategy and Changing

Moods in Thucydides

\title{
Glenn Perusek
}

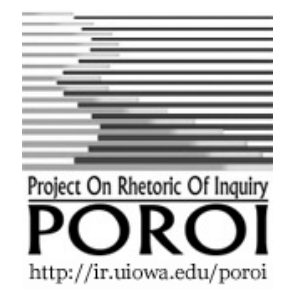

Poroi, 3, 2, December, 2004

1 Thucydides offered a political language that is not necessarily available in our lexicons of politics. Often his history is characterized as a realist or strictly empirical description of the Peloponnesian War. Yet it also provides a tragic account of the wages of hubris. This essay advances that reading, contending that Thucydides enhanced his telling of the tragedy by attending to moods of the Athenian polis. Political moods are the changeable temper of a polity: a vital factor to be harnessed or counteracted by political leaders. The collective moods of citizens in the Athenian assembly loom large in Thucydides' tale of the war. Moods, notably hubris and demoralization, also grip Athenian leaders of the war effort.

2 The very vocabulary of Thucydides treats moods of Athenians as crucial grounds for strategic speech and action. His history features a series of internally inseparable concepts that encompass reasons and moods. These terms do not observe later contrasts between calculations of rationality and considerations of sentiment. They evidence how Thucydides stressed moods as grounds for strategic interventions. Here I interpret in context four of these key terms - gnome, kataphronesis, elpis and epistamai- to show that Thucydides did not operate with a strict dichotomy between reason and mood. To read these concepts carefully is to bring out the political lessons of Thucydides.

3 The historical significance of the Peloponnesian War and the text of Thucydides can scarcely be overestimated. Athens, the great democratic polis, rose to imperial dominance in ancient Greece and became the apex of classical culture in the decades after its victory over the Persians at the beginning of the fifth century bce. Then its defeat in the Peloponnesian War signaled a decisive turning point for this polity and culture. Thucydides' history, long held to be a founding document in the discipline of history, is a powerful account of the causes of Athenian defeat. Thucydides addressed the problems associated with the maintenance of a polis 
that is simultaneously democratic and imperial. The enduring significance of this theme should be apparent today. Under Perikles, the Athenian polis followed a strategy of limited aims; after his death, it descended into vicious overreaching that led ultimately to demoralization.

4 Recent readers often take Thucydides to be a paragon of realism. He is the hard-nosed author of the Melian dialogue, where the strong do what they will and the weak suffer what they must. This Thucydides is an unsentimental, empirical historian of his day, devoted mainly to describing a great war. But the Melian dialogue is prologue to the Sicilian campaign, the tragic episode of overextension of Athens and their destruction in the great battles with Syracuse, the main Sicilian polis, and their Peloponnesian allies. Thucydides narrated the episode in highly dramatic style. The modern distinction between empirical-realist history and dramatic-tragic storytelling does not capture the full power of Thucydides' account. ${ }^{1}$ If we read the Melian dialogue in connection with the Sicilian campaign, we might arrive at an interpretation directly opposed to realism: While the strong believe they can do what they are able to do, they often misassess their circumstances, overreach, and come to suffer defeat as a result.

5 The Melian episode occurred in the summer of 416 bce. The following winter, 416/415, the Athenians contemplated their grand expedition to Sicily. In the beginning - in the very first sentence of his account, Thucydides pointed out that they misestimated the size of the island, the number of its inhabitants, and therefore the enormity of the task they proposed to accomplish. Estimations and the moods of generals and citizen-soldiers that cloud or distort them - are a vital element in the tragic course of the war for Athens.

6 In a note to one of Nikias' exhortations to Athenian soldiers in the Sicilian campaign, scholar-translator David Grene writes that:

Nothing stands out clearer throughout Book vii than the necessity under which the Athenian generals stood of taking account of the morale of their men from moment to moment. Even if this is true of any army at any time, the present case is extreme and its extremity proves the nature of the Athenian forces. These are citizens first and soldiers after. ... Here these citizens-in-arms were far from home, frightened 
and bewildered by the unexpected success of an enemy they had thought to defeat with little trouble. Consequently, from the first to last their commanders had to persuade them, like an election meeting, of the necessity of fighting bravely. ${ }^{2}$

What Grene says for Book 7 is in fact a leading theme throughout Thucydides' work. The collective mood of the citizens of the Athenian assembly - or the troops of the Athenian armies and navies - is a vital factor in Thucydides' description of the course of the war. This mood was highly changeable, and political and military leaders at times take advantage of it for their own purposes. At other times they counter or divert it, and sometimes they must acquiesce to it.

7 Francis Cornford contended that Thucydides' original intention of providing a realistic description of the course of the war, as a manual of strategy, was ultimately overlaid with a dramatic account of the tragedy of Athens. Thucydides could not escape the influence of his own cultural context. ${ }^{3}$ Cornford is right to emphasize the tragic and dramatic elements in Thucydides' work, but these need not be seen as so fundamentally counter-posed to any realist, empirical, descriptive design. There is indeed a strong strategic lesson in Thucydides' story: for politicians or statesmen, war leaders, and citizens alike. Unbridled passions -

overreaching, striving for more land, seeking conquest, and the full venting of violent revenge on enemies - will be unleashed in wartime. Prudent leaders take care to moderate these tendencies in themselves, in their generals and soldiers, and in the citizenry.

8 These passions are aspects of moods, themselves vital elements in tragic drama. All aspects of moods must be taken fully into consideration by strategic leaders. Thucydides used a rich vocabulary to describe these moods, weaving it into his description of the decisions and actions of the war. It is this rich, complex fabric of description and drama that imparts to Thucydides' history its enduring quality. He preferred fidelity to events to a purely artful rendering. This led him to trace war events according to "what belongs to humankind," particularly our struggles with tragic passions.

\section{Prudent-Moderation (sophrosune)}

9 Coming of age during the Peloponnesian War, Plato had hopes for correcting the ills of democracy. These were disappointed by the 
Thirty Tyrants, led by his uncle, Critias, who came to power briefly in 404. After the war, the democracy 's retribution against Plato's teacher, Socrates, further cemented Plato's disillusionment. A sane moderation in politics, from any quarter, seemed beyond reach; so the young writer withdrew from public life. The "madness of the majority" made the quiet pursuit of philosophy all the more appealing. ${ }^{4}$ This experience formed the backdrop for the rigidly idealistic theory of the state that Plato developed in the middle dialogues - most notably, of course, in the Republic.

10 Plato's ideal state distinguishes sharply among three classes: the guardians (phulakes), who pursue wisdom and provide good counsel; the auxiliary guardians, who make up the fighting force and feature the virtue of courage; and the ordinary citizens, who manifest moderation (sophrosune). Statecraft and education instill this moderation. The authority of the phulakes tempers the pleasures and desires of ordinary citizens, in two ways. The phulakes act to moderate citizen desires; and ordinary citizens recognize their own place, to "do their own work." They do not meddle in affairs of state. Sophrosune might be called the master virtue of the three. It spreads throughout the polis, making all harmonious. But justice - dikaiosune, indication, the "right way" - is a consequence of sophrosune; and single-minded dedication to "one's own work" is its hallmark. ${ }^{5}$

11 Plato analogized the well-governed polis to the properly ordered individual soul, which also has three parts. Strong arguments for Plato's polis arise from the suitability of the model for individuals. The person governed by an excess of courage - by anger, rather than by wisdom - would be dangerous to himself and others, just as the person ruled by desire for pleasures - food, drink, sex would be self-destructive and out of control. That reason should command makes sense by comparison, but this has led some to class Plato as anti-emotional or at least coldly intellectual. ${ }^{6}$ Yet in Book 9 of the Republic, Plato makes it clear that each type of person, and each part of the soul, has its own pleasure and its own desire. We can speak of the wisdom-loving, the honor-loving, and the acquisition-loving persons. The soul of the warrior would be directed by the desire for honor or victory; the soul of the moneyor food-loving person by the desire for acquisition. ${ }^{7}$

12 Providing a "magnificent defense of emotion," the Symposium also suggests that Plato was far from coldly intellectual. The key section of this dialogue has Socrates reporting the teaching of Diotima, a wise woman, who termed love a great intermediary that 
interprets spirit.8 Ideally love leads from bodies to souls, from the world of the concrete to increasingly abstract and general things, and ultimately to the forms. Loves draws us toward "contemplating the vast sea of beauty," which is "absolute, separate, simple, and everlasting."9 But this is the ideal; in practice, the dialogue concludes with such problems of love as misdirection and inappropriate infatuation. It is Alkibiades, drunk and disorderly, who enters the dialogue and provides an object lesson in the dangers of desire. Socrates has tried to instruct him; but as Alkibiades himself says, "when I leave his presence the love of popularity gets the better of me."10 Alkibiades is jealous and self-centered. He wants Socrates only for himself and is angered at the philosopher's repeated rejection. The thoughtful drinking party breaks up because of the same man central to the destruction of Athenians in the Sicilian expedition that Thucydides described at the conclusion of his work on the war.

13 The teaching of sophrosune, that hubristic overreaching gets punished, is a leading theme in Greek literature of the fifth century. In Agamemnon by Aeschylus, Klytemnestra voices her concern that the sackers of Troy not disturb the shrines. They must recognize the gods of conquered cities, they must not plunder. ${ }^{11}$ But they have already plundered, leaving them unprotected on their journey home. In Prometheus Bound, Hermes accuses Prometheus of being struck mad (phrenoplekton). Time has not taught him sophronein, to be moderately-prudent. ${ }^{12}$ His insolent overreaching is to give mortals fire and other skills from the heavens. And in the Persians, the ghost of Darius laments his son's ill-fated expedition across the sea against the Greeks. The destruction of the Persian army is punishment for hubris and phronematon, wanton violence and godlessly overbearing pride. ${ }^{13}$ The Persians march through Hellas destroying sacred shrines; their sacrilege is repaid in suffering. These evil deeds merit the heaps of corpses that their armies become as a silent sign that man is mortal and should learn to curb his pride. Their human failing is to despise their present fortune and instead to lust for more. The gods punish such overbearing arrogance, huperkompos, overstepping of bounds; and they warn Xerxes to take a course of prudent moderation, sophrosune. ${ }^{14}$

\section{Perikles: Strategic Boldness Coupled with Moderate War Aims}

14 In the account of Thucydides, Perikles, the great Athenian general and political leader, establishes a standard for prudent and far- 
seeing leadership. In his first major speech, Perikles attends to the mood of Athens at the outset of the war. Perikles begins by noting the changeability of the Athenians. His resolution (spirit, viewpoint, gnome) is to yield nothing to the Peloponnesians, even though he recognizes the danger that Athens will be of one spirit (passion, orge) in the assembly but another in the war's execution. As circumstances change, resolutions change (1.140).

15 In his initial material estimation, Perikles sees Sparta advantaged in single combat but without the funds for a longer war. The Athenian fleet is a permanent or insuperable advantage, because it would take generations for Sparta to achieve the skill that Athens has been developing since even before the Persian invasion. Yet this objective asymmetry - between the formidable land force of Sparta and the naval superiority of Athens - necessitates a willingness by Athens to sacrifice Attic territory, and to make up for lost supplies from its empire: the islands and other holdings. "Dismissing all thought of our land and houses, we must vigilantly guard the sea and the city" (1.143.5). Perikles warns the Athenians that they must not engage the Peloponnesian forces on land, for it will spell certain defeat. Instead Athens must maintain its fleet, its link to the empire that is the source of its strength.

16 It is an incredibly bold plan, not least because it entails a move that will surprise Sparta: the sacrifice of houses and land in the Attic countryside. Perikles closes the strategic exposition with a rhetorical flourish. "If I thought I could convince you," he says, "I would suggest you go out and destroy the houses yourselves, to show the Spartans that their razing them will not force us to submit to them" (1.143.5). Crucial for success, however, is the fortitude and moderation of Athens. It must not seek to enlarge its empire. The question of Sicily may well have been in Perikles' mind. Although the major invasion of Sicily did not occur until 415 , designs on Sicily existed long before the war's outbreak. Plutarch wrote that, at least as early as 448 , "many were already possessed by that fatal passion for Sicily which later was inflamed by Alkibiades and his friends. Some dreamed even of Carthage and Etruria."15 Yet Athens must firmly dedicate itself to Perikles' plan. Athenian alacrity itself will dampen the ardor of its enemies (1.144.3).

\section{The War Begins (2.8-2.22)}

17 Enthusiasm for the war is greatest at the beginning, especially among the young, who had no previous experience of war (2.8.1). 
The favor of most of Hellas is with the Peloponnesian allies. (Thucydides used eunoia, good minds.) This is because there is general indignation against the empire. Many in it wish to escape, and others fear subjugation. Once again, Perikles wishes to restrain Athens from seeking more. Its empire has created a hostile spirit among the Greek peoples (2.8.4-5).

18 With such preparations and spirit (gnome), Athens rushes (hormento) into the war (2.9.1). This sentence is especially important. First, the use of gnome makes it difficult to differentiate feelings from mentalities. It follows a discussion of moods in the Athenian and Peloponnesian polei, and it is informed by the sense of hostility that the rest of Greece feels toward the Athenian empire. J ust as Geist is hard to translate from German to English, because it means both mind and spirit, gnome encompasses feelings and judgments. Associated with judgment or intelligence (1.140.1) as the gnome of Perikles, it also suggests inclination. When Argos inclines toward Athens, the term is gnome (5.44). At 6.45, when the Syracusans make a full commitment to defense, preparing with all diligence, their purpose is their gnome. When the Spartans develop new aims, they have changed gnome (3.92.1). And when Corinth calls for united opposition to Athenian power, the purpose word is gnome (1.122.2). Second, the use of hormento seems to foreshadow tragedy: under the sage leadership of Perikles, the zeal of the inexperienced young is a condition for rushing into the war.

19 Difficulties quickly challenge the military leadership of Athens. The boldness of Perikles' plan - necessitating the abandonment of the countryside - is difficult for the Athenians to accept in practice (2.16.2). Perikles had warned the Athenians that they must sacrifice the countryside and rely on the fleet. They accept this in the assembly. Yet he warned that the changeability of their gnome in the course of the war could be their downfall. Trouble would ensue if they either lost resolve or sought expansion of the empire. Merely a year later, the Athenians see the first invasion of Attic territory as unendurable. It is a grievous insult; and the young, especially, want to confront the invaders (2.21.2). Excited dialogues in the street trump the counsels of Perikles. They abuse him for refusing to lead the army out and blame him for public suffering. Seeing anger and poor judgment in ascendance, Perikles refuses to call an assembly. 


\section{Athens after the Second Spartan Invasion (2.59-2.65)}

20 A second invasion ravages the countryside, crowds the population inside the city walls, and contributes to an outbreak of plague. These hardships lead Athenians to lose resolve, change gnome (2.59.1). The trouble identified by Perikles in his initial speech (1.140.1) has once again come to pass. Gnome suggests the will of Athenians more than their intelligence. It highlights their judgment in the sense that their misfortunes have led to a more fearful, fatalistic pessimism. They have changed their minds, but more than that they have a new spirit or mood. Holding Perikles responsible for their hardships, they are eager (hormento) to reach terms with Sparta. Their despair is deep; their gnome is impassable, aporoi. They see no way out.

21 Perikles calls an assembly to encourage them, to inspire them, to lead them from anger to calm and fearless resolution. Perikles patiently explains to the Athenians that, even though they are thoroughly dismayed at the situation and hold him responsible, steadiness of purpose can lead them beyond present misfortunes. They are now in a weakened state of purpose (gnome), one that has turned against him in light of their misfortunes (2.61.2). The biggest blow to Athens is the appearance of the unexpected, the plague. The unexpected enslaves the spirit (phronema) (2.61.3). After calling on their public-spiritedness, their willingness to sacrifice for the commonwealth, Perikles encourages the Athenians by emphasizing their special excellence, their utter naval superiority. In a striking phrase, Perikles calls on Athens to confront its enemies not merely with spirit but with arrogance or contempt (me phronemati alla kai kataphronemati) (2.62.3), which should spring from a recognition of Athenian naval superiority.

22 Why would Thucydides use such a negative term in the Perikles speech? The contrast at 2.62.4 may be helpful: "For pride (boasting, auchema) comes from ignorant good fortune and is available to any coward; while supremely confident arrogant contempt (kataphronesis), which comes from trusting knowledge of prevailing over our enemies, is our situation." Perikles is speaking to an audience disheartened, even panicked, by unexpected events. ${ }^{16}$ The contrast is between (empty) boasting and (justified) contempt of the enemy. Naval superiority justifies the contempt. An adequate sense of the situation is what differentiates trusting knowledge from ignorant good fortune. Any 
fool can boast; arrogance born of advantage is not empty posturing. Perikles is telling the Athenians to believe that they will prevail because their naval superiority is a material fact.

23 The only other such use of kataphronesis in Thucydides is the speech by Hermokrates to the Syracusans (6.33-34). At first, Hermokrates warns the Syracusans not to underestimate the danger of an Athenian invasion. "Do not allow yourselves to be taken unguarded through contempt (kataphronesis), nor through disbelieving neglect the common good" (6.33.3). At the end of his speech, after Hermokrates has called for an active defense, he says that contempt for the invader will be shown through the strength of deeds. He contrasts this to the complacent talking down of the threat that had been occurring in the assembly. Yet Hermokrates is unable to shake the Syracusans, who resist recognizing that contempt for the Athenian threat requires rapid preparation for war.

24 This positive use of kataphronesis in speeches by Perikles and by Hermokrates expresses hyperbole in the heat of an argument. In both cases, "real" kataphronesis, based on knowledge of some strategic superiority, contrasts with empty boasting. Perikles underlines for the Athenians their distinctive excellence, calling on them to be bold once more, even after their setbacks. Here kataphronesis is a supreme confidence: the mood of people sure of themselves in light of their powers and plans. It is a mood secured by trust in knowledge, stepping outside the dichotomy between reason and emotion.

25 Persuaded, the Athenians do not send envoys of peace to Sparta. Poor and rich, despite their suffering, recover enthusiasm for war (polemon mallon hormento) (2.65.2). But crowds are changeable: not until they fine Perikles does their passionate temperament (orge) toward him cease (2.65.3). Soon, though, they turn around to elect him general again, entrusting affairs of the war to him.

26 Thucydides characterized the rule of Perikles as measured, metrios, summarizing the war policy of Perikles in a phrase: "He said to wait quietly (hesuchazontas) and attend to the fleet and to take no new acquisitions in war, which would bring danger to the polis" (2.65.7). It was an "unambitious" policy, a defensive policy of strictly limited objectives. It sought to secure the imperial possessions Athens already had. Yet the willingness to sacrifice the Attic countryside is a bold stroke in the midst of the policy. Thucydides admires this combination of vigorous action, 
emphasized at 1.140, and moderate goals. The statesmen after Perikles, in contrast, "managed affairs in the opposite way. . . . In accordance with personal ambition and personal gain they pursued other policies that seemed unrelated to the war, to the detriment of both themselves and the allies, since, when these succeeded, they brought honor and benefit more to individuals but, when they failed, they did damage to the city regarding the war" (2.65.7, Lattimore).

27 Basing Athenian policy on naval superiority, Perikles tries to focus Athens on specific aims and tactics. Those who come after him do the opposite: goaded by love of individual glory and gain, they involve Athens in dangerous or spurious adventures. They necessarily stumble, harming the polis. Perikles, the first man of Athens, rules through reputation, judgment (gnome), and clear incorruptibility. He need not pander to the assembly; he "rules instead of being ruled by" the masses. Personal acquisition never interests him. When the assembly needs to hear hard truths, he never shrinks from the responsibility. His repute is so high that he can manage the passions (orgen) of the crowd (2.65.8). Whenever he perceives the crowd to be arrogant, insolently over-confident (hubrei tharsountas), or otherwise outside due measure (para kairon), he shocks them into fear (kataplessen epi to phobeisthai). Yet when they are unreasonably fearful, he restores them to courage (tharsein) (2.65.9). ${ }^{17}$

28 The preeminence of Perikles gives way to more equal, contentious antagonists for power. Men stretch (oregomenoi) to become first. They pander to the assembly, deferring to the pleasure of the people (2.65.10). Then the Athenians make mistakes, especially in sailing to Sicily, although Thucydides faulted bad estimations of Sicily less than imperial intrigues that diverted Athens and led to its downfall (2.65.11).

\section{Episodes of Overreaching: Mytilene, Pylos, and Melos}

29 After the death of Perikles, overreaching leaders come to the fore in Athens. Kleon and Alkibiades, in particular, are key figures in Thucydides' drama of Athens as a democratic empire that falls into a madness of mood and policy.

\section{Suppression of the Mytilene Revolt (3.35-3.50)}

30 In 428-427, oligarchic leaders of Mytilene stage an ultimately 
unsuccessful revolt against the Athenian empire. Many among the Mytileneans oppose the anti-Athenian revolt. Yet when the revolt's leaders are delivered to Athens, the Athenians decide "in the fury of the moment" (hupo orge) to kill all the adult males of Mytilene and to enslave all its women and children (3.36.2). But the next day, the Athenians recoil from this harsh penalty. They quickly recognize their error and reconsider the savage decision (3.36.4). The main advocate of the terrible penalty for Mytilene is Kleon, a popular demagogue and "the most violent man at Athens" (3.36.6).

31 In the history of Thucydides, Kleon speaks for the mood of Athenians in wishing to annihilate Mytilene. As the assembly reconsiders its vote (3.37-40), Kleon attacks the assembly itself. He argues that democracy is incapable of the harsh actions required to maintain obedience in an empire. Strength (ischui), rather than good will (eunoia) or friendly gestures (charizesthe), maintains the empire (3.37.2). Particularly dangerous is indecision: the unwillingness to stay with decisions. Implacable force serves the imperial polis better than humane but toothless laws (3.37.3). Blind discipline, in the empire and the assembly, is superior to cunning indiscipline. Kleon calls for an unthinking obedience in the assembly and the empire. Those who wish to reconsider the Mytilene punishment are sophistic. They would distract the imperial polis from its purpose by having Athens proceed with its passion, its anger, blunted (3.38.1). Temporizing, exercising conscience, seeking to get policy right: Kleon condemns them all.

32 In a strikingly prophetic passage, Kleon himself condemns hubristic overreaching. The Mytileneans had moved boldly. With expectations (elpisates) greater than their powers, but not their ambitions, they had gone to war supposing that strength (ischun) is more worthy than right (dikaiou). Customarily in wars, the most unexpected good fortune turns people to hubris (3.39.3-4). With these words of accusation against Mytilene, Kleon foreshadows his own overreaching (pleonekteo) - grasping for more than is deserved - after Athenian good fortune at Pylos. His words also reach forward ironically to Athenian policy towards Melos. Kleon calls on the empire to act rashly, passionately, and viciously; but when a small power does, it is arrogant. Did Thucydides want us to read Kleon's words as a condemnation of the arrogance of Athens in the Melian case? Do Kleon's words presage condemnation of the Athenian campaign in Sicily? The Athenians proceeded with excessive hope, believing their own 
strength sufficient reason to subdue far-off Sicily: strength more worthy than right led to arrogant insolence. The Athenian failure in Sicily is punishment for this arrogant overreaching.

33 Tapping a heated mood of vengeance, Kleon nearly persuades Athens to punish the Mytileneans excessively. Provided by Thucydides, the response by Diodotos is calm and deliberative. It just barely draws Athens back from the brink. The two great enemies of good counsel, Diodotos begins, are haste (tachos) and anger (passion, orgen). These bring senselessness (anoias), lack of control (apaideusias), and short or scant thought (brachutetos gnomes) (3.42.1). Logos must inform action; only the ignorant or personally interested would maintain otherwise. Contrary to Kleon, Diodotos emphasizes that his standard is not justice for Mytileneans but advantage for Athenians. He concedes that Kleon's speech accords with the present passion of Athens, but he says the assembly's task is statecraft. Extreme punishment will not deter potential rebels. Cities in revolt against the empire will fight to the last if they know the punishment for failure is death. Like other polei, moreover, Mytilene is divided between popular and oligarchic elements. What Kleon advocates, essentially, is butchering the people of Mytilene, "who had nothing to do with the revolt." Athens should encourage the favor and friendship of this class, not cut it off. In the end, Athens returns to calm conscience, rescinding its harsh vote. With Mytilene in 427, the madness, born of anger, is momentary. With Melos in 416, it becomes the policy of Athens.

34 In an expansive section (3.45) of his speech, Diodotos dilates on the ubiquity of human striving. Again this foreshadows the tragic fall of Athens in the Sicilian campaign. He contends that passions are an incurable force, leading men into danger, whether they are poor or rich. Wealth leads to insolent confidence and overreaching (hubrei ten pleonexian kai phronemati) (3.45.4). Expectation (elpis) abets orge by devising plans; desire (eros) by undergirding them with good fortune. 18 What is it to expect? In the positive, this Thucydides word encompasses an estimation of prospects from projecting current situations plus a mood of hope, optimism, or the like. In the negative, it is a despairing or pessimistic anticipation of future events. The judgment and the feeling proceed together, inseparably. In expectation, moods inform calculations in part and emerge in part from them. Thus expectation (elpis) is an internally inseparable concept that combines mood and calculation. 


\section{From Pylos to Melos}

35 Another important episode is the campaign at Pylos, on Peloponnesian territory. Athens experiences unexpected good fortune in capturing it. When reinforcements led by Kleon seize nearly three hundred hostages from Sparta and its allies, Athens is in a position to negotiate a favorable peace. Thucydides suggests that this was a highly opportune moment to end the war and to strengthen the Athenian empire by securing an alliance with Sparta. In the negotiations following Athens' first victory at Pylos, Spartan envoys acknowledge the strong situation of their rivals, but warn that such good fortune is fleeting. Athens rejects their offer of peace and alliance, and instead, under the influence of Kleon, grasp at more than is deserved, pleonos oregonto (4.21.2). A second battle is then fought at Pylos, which Thucydides described as the greatest anomaly of the entire war, as it resulted in victory for Kleon's mad intransigence (4.39.3). Once again Athens refuses to negotiate peace with Sparta; they are meizonton te oregonto, stretching out for more (4.41.4). Were Athenian statesmen to observe Periklean limits, their first concern would be to secure the existing empire. Goaded by a surprisingly successful Kleon, however, the assembly turns intransigent; and that mood dooms negotiations with Sparta.

36 In his speech on the eve of the first battle at Pylos (4.10), Demosthenes reverses the standard relation of hope (elpis) and purpose (gnome). He asks the troops to shun the appearance of intelligence through calculating dangers; instead they should act in good hopes (euelpis) of prevailing. Such critical moments call for resolute and rapid action, not calculation. 'Don't think, but act,' Demosthenes says in effect. But even as he warns the soldiers against calculations, he demonstrates that he has made them to conclude that the situation confers a single, decisive advantage on the Athenians. The Spartans are more numerous, but that won't matter if the Athenians stand their ground, because the rocky terrain prevents access except in a few places. Defending these chokepoints, the Athenians need not fear the numerical superiority of their opponent. 19

37 Following the death of Kleon, new leaders come to the fore in Athens and Sparta. A precarious peace prevails for some years. By 418, a new war leader, Alkibiades, denounces the treaty and upsets the peace. The Athenian expedition to Melos signals the return to Kleon's approach. Initially colonists from Sparta, the Melians seek to stay outside the larger struggle; but the Athenians insist that the 
Melians, like other islanders, submit to the Athenian empire. When Melians offer only a friendly neutrality, Athenians besiege the island polis. The fifth book by Thucydides ends with all grown men on Melos put to death and all women and children sold into slavery. Although a serene mood of calculation suffuses the Melian dialogue, the words and deeds of the Athenians betray a mad spirit of blindness and insolence. ${ }^{20}$ They calmly ridicule all Melian hope for the future.

\section{The Sicilian Campaign}

38 The immediate sequel to the ruthless obliteration of Melos is the Sicilian campaign; it bears the poison fruits of Athenian hubris. The first sentence suggests that the expedition arises from awful miscalculation. The assembly is eager to subjugate Sicily, even though Athenians know little about the size of the island or the number of its inhabitants (6.1.1). They undertake a war "not much inferior" to the one they waged against the Peloponnesians. From the outset, Thucydides left no doubt that he considered the Sicilian campaign a fatal overreach for Athens.

\section{Nikias before the Athenian Assembly (6.9-6.13)}

39 To the assembly, Nikias speaks against the Sicilian campaign. He acknowledges the assembly's risk-taking sensibility but suggests that in this case the haste is untimely (oute en kairoi) (6.9.3). Nikias echoes Perikles. Athens already has many enemies in Hellas; the Sicilian campaign would only augment its foes. The treaty with Sparta is not secure. Sending large parts of the Athenian fleet and hoplites to Sicily would make Athens vulnerable. Hellenic polei would seize the opportunity to attack Athens if they find its power divided (6.10.4). Campaigning in Sicily amounts to "grasping (oregesthai) at another empire before we have secured the one we have already" (6.10.5). With the empire insecure at home, even a victory in Sicily would leave that island hard to govern. It is "too far off and too numerous to be ruled without difficulty" (6.11.1).

40 Athens should instead hold its power as a threat - an unmade move - against Sicily. "The Hellenes in Sicily would fear us most (ekpeplegmenoi) if we never went there at all" (6.11.4). Athens is fortunate to be in its present situation; it is fortunate to have the victories that pave the way to a favorable peace. The danger is to become overconfident (kataphronesantes) on the basis of this good fortune (6.11.5). Nikias admits that his strategy is defensive. 
He is more concerned to keep watch on the empire "at home" than to augment it abroad (6.11.7). He worries that the young are possessed by a "fatal desire," that they literally are "sick in love" (duserotas) with the far away. He cautions that desire (epithumiai) attains little, foresight (pronoiai) much (6.13.1). A "mad dream of conquest" produces this expedition; Athens is gravely endangered by it (6.13.1).

\section{The Speech of Alkibiades}

41 Thucydides characterized Alkibiades - the attractive, energetic, charismatic, profligate young leader - as personally ambitious. He opposes Nikias in Athens but also seeks glory and wealth from destroying Sicily and Carthage (6.15.2). ${ }^{21}$ Alkibiades has passions (epithumiais) greater than his estate could support (6.15.3). This results in the destruction (katheilen) of the Athenian polis. ${ }^{22}$ The many fear the greatness of Alkibiades' transgressions (paranomias) in personal life, thinking them worthy of one who desires (epithumounti) tyranny.

42 Alkibiades says that his passion causes Sparta to fear him. His orgei, his senselessness contrary to nature (anoia para phusin), his "credibility through ardor" as Lattimore has it, makes the Peloponnesians tremble before him. Alkibiades suggests that the Sicilian polei are not strong opponents. The peoples of Sicily are divided, selfish, and mobile: no match for the well-equipped Athenians (6.17.4). Athens can benefit from barbarian hostility to Syracuse. Moreover the great strength of Athens, the navy, is the great weakness of Sparta, which cannot be expected to aid Syracuse. The Athenian empire can be expanded, and Alkibiades argues this is imperative if the empire is to be kept. If Athens remains inactive, and forms of hesuchon appear twice, at 6.18.2 and 6.18.3, it is in danger of being subdued by others. "We have reached a position in which we must not be content with retaining what we have but must scheme to extend it or, if we cease to rule others, we shall be in danger of being ruled ourselves" (6.18.3). Athens should show the Peloponnesians contempt (huperidontes) for the present peace (or "ease," again a form of hesuchon).

43 In short, Alkibiades holds out the prospect of empire over the whole Greek world. The bold stroke against Sicily would strengthen the empire, even at home. It would "humble the pride" of the Peloponnesians and ruin the Syracusans. At base, Athens could always count on its naval superiority. The alternative is the "passive policy" of Nikias. If Athens allows itself to "sink into 
inaction" (apragmosunes), its skills would decay, and it could not defend itself. "A city not inactive by nature could not choose a quicker way to ruin itself than by suddenly adopting such a policy" (6.18.7).

\section{Nikias' Second Speech}

44 After hearing Alkibiades, along with representatives of the Egesteans and the Leontine exiles, the assembly "became more eager" (hormento) for the expedition. Sensing the change of mood, Nikias alters tactics. Now he would dissuade Athens by stressing the expedition's need for costly preparations. Nikias calls for the largest hoplite force possible plus "overwhelming superiority at sea." But his estimation of the expedition's magnitude makes the assembly more avid than ever. It does not hear his caution that even a well-armed invasion of Sicily is risky but believe instead that "the expedition would be the safest in the world."

Everyone fell in love with the enterprise. The older men thought that they would either subdue the places against which they were to sail, or at all events, with so large a force, meet with no disaster; those in the prime of life felt a longing for foreign sights and spectacles, and had no doubt that they should come safe home again; while the idea of the common people and the soldiery was to earn wages at the moment, and make conquests that would supply a never-ending fund of pay for the future (6.24.3, Crawley).

War fever grips Athens. The few with reservations hold back, unwilling to appear "unpatriotic" to the enthusiastic, overwhelming majority.

\section{Convinced Knowing (epistamai)}

45 The knowledge word, epistamai, is the root for epistemology. It translates into "scientific knowledge" in English and other modern languages. Used abundantly by Homer, it refers both to intellectual power ${ }^{23}$ and artistic skill, ${ }^{24}$ as in the "dancer's knowing (epistamenoisi) feet (Iliad 18.599)." In the fifth century, epistamai connotes assurance or confidence. ${ }^{25}$ Urging Darius to war, Atossa argues (in the words of Herodotus at 3.134) that Darius is a great ruler but idle, so that the Persians need to know 
(ekmathosi) they are ruled by a great man. The benefit would be double: not only will the Persians know (episteontai) Darius as a great man, but they also will be worn down by war and become less of a threat. Darius resolves to investigate Greece for a possible invasion. The spies "will discover (mathotes) and see and tell us ever detail."26 Here epistamai evokes a conviction absent from other Greek words for knowledge. Once Darius acts, the Persians will have a convinced knowledge of his greatness. It goes beyond the investigatory knowledge of the spies, which Herodotus terms mathein.

46 Confident or convinced knowledge also appears in Herodotus at 6.139. Pythia tells the Pelasgians to give the Athenians whatever they desire. The request is for the Pelasgian territory. The response is that, when a ship can travel from Athens to Pelasgian territory in a single day, with a north wind, we will give you our land. The Pelagians are "well assured" (epistamenoi) that this is impossible, since Attica is far to the south of Lemnos. The confidence of the Pelasgians is akin to Macbeth's, when the Apparition tells him why he can be certain to rule. ${ }^{27}$

47 Aeschylus employs a similar contrast in Prometheus, 375-380. Prometheus thinks it would be futile for Oceanus to intervene on his behalf with Zeus.

Prometheus: You are not inexperienced; you do not need teaching from me. Save yourself as you best know how (epistasai). I will bail the present fortune, until the mind-of-bile of Zeus abates (phronema lophesei cholou).

Oceanus: Do you not know (gignoskeis), Prometheus, that words are a cure for the passiondisease?

Here epistamai suggests a kind of craft knowledge by contrast with the theoretical knowledge (gignosko), that words can cure the orge sickness. In principle, logoi (words or arguments, in the plural) can cure the "choloric" phronema of Zeus. In practice, Oceanus knows for sure how to survive.

48 Thucydides saw the Athenians as bitter that the sacrilege against the Hermae might be part of an oligarchic or tyrannical plot against Athens. Their convinced knowing (epistato) is of the 
history of oligarchy (6.60.1), and it spurs a contagious fury to find the perpetrators of the outrage. For Thucydides, their convinced knowing is tragic, as "many worthy men had already been cast in prison; and yet they were not likely so to give over, but grew daily more savage, and sought to apprehend more still" (6.60, Hobbes). Theirs is the knowing conviction of a mob, ever more savage in pursuit of the guilty. One of those in custody provides an accusation, "whether true or not." A mood of righteous anger pervades the episode. Accusing fingers point at Alkibiades, and the polis sends a trireme to Sicily to retrieve him for trial. Given the mood of Athens, Alkibiades escapes instead. Sentenced to death in absentia, he soon goes to Sparta, where he provides the enemy with valuable perspective on the Athenian plans that he had been so instrumental in crafting.

49 Syracuse fears that Athens will attack immediately. When it does not, the Syracusans recover their courage and become arrogantly contemptuous (katephronesan) in pressing their generals to lead them against the Athenian camp at Katana. The Athenian generals see this as an opportunity. They send a Katanian trusted by Syracuse to say that the Athenians spend nights in the city, far from their armaments. If the Syracusans would name a day and come at dawn, their allies in the city would close the Athenians inside the gates and set fire to their ships.

50 Full of confidence (tharsein), the Syracusan generals believe the Katanian uncritically. As they attack, the Athenians transport hoplites by ship to Syracuse, where they land without opposition. The Syracusans must scramble back to defend their polis. The next day sees the first battle between Athens and Syracuse. Thucydides judged the Syracusans to be courageous but lacking experience. They fight evenly for a long time, but a sudden thunderstorm disconcerts and puts them in fear (phobou) (6.70.1). The momentary alarm tips the balance. Syracuse loses 260 soldiers; Athens and its allies about 50. But the Athenian generals recognize that war cannot be waged in winter close to Syracuse without reinforcement by cavalry from home, so they depart for Katana for the winter (6.71).

51 Hermokrates, the leading figure of Syracuse, comes forward to encourage the assembly. "Their courage, he said, was not overcome, though their want of order had done them hurt," as Hobbes translated (6.72.3).28 Hermokrates proposes a reorganization of the Syracusan force along with arming and training the soldiers that winter so they would be better prepared 
for the Athenians in the spring. "For valor they had already, and to keep their order would be learnt by practice; and both of these would still grow greater: skill, by practicing with danger; and their courage (tharsaleoteran) would grow bolder of itself, upon the confidence of skill (meta tou pistou tes epistemes)" (6.72.4, Hobbes). Note the interpenetration of courage, confidence, and belief with skill, knowledge, and mind. No strict division of the head from the heart or reasoning from confidence and courage could come to good terms with meta tou pistou tes epistemes, the "confidence of skill."

\section{Turning Points: Changing Momentum in Sicily}

52 The Syracusans determine that the Epipolae, the high ground situated directly above their city, is vital to the Athenian attack. Killing three hundred Syracusan infantry, the Athenians still win the first battle. Disorder (ataktoteron) again produces Syracusan defeat (6.97.4). The Athenians build a fort at Labdalum, on the far side of the Epipolae, away from Syracuse, for storing resources. Significant reinforcements from Egestea and Katana nowjoin Athens, which begins to build a wall around Syracuse. Shocked (ekplexin) by the rapid progress of the Athenians, Syracusan generals cannot order their troops for battle. They retreat into the city, leaving only horsemen to harass the Athenians (6.98.2-3). As work on the wall proceeds, the Syracusans determine that they cannot risk further battle, and they decide to build a counter-wall instead. The Athenians attack and destroy it along with the underground pipes that carry drinking water into the city (6.100). Then the Athenians sail their fleet into the harbor, reuniting their forces.

53 Athens has the momentum. Italy sends provisions. Sicilians "who before stood aloof to observe the way of fortune" join the Athenians (6.103.2, Hobbes). "Meanwhile everything else progressed favorably for their hopes. The Syracusans began to despair of finding safety in arms, no relief having reached them from the Peloponnesus, and were now proposing terms of capitulation among themselves and to Nikias" (6.103.2-3). The Syracusans are aporos, trackless, without a way. What's more, they divide internally. "Their present misfortunes had also made them suspicious (hupopsian) of one another; and the blame of their disasters was thrown upon the ill-fortune or treachery (prodosiai, giving up) of the generals under whose command they had happened" (6.103.4). They elect new generals to replace the 
old.

54 Going to relieve Syracuse, the Spartan general Gylippos hears bad news of the battle. An incorrect report that Athenians have completed their wall leads him to abandon hope for Sicily and turn to saving Italy. Crossing to Tarentum, he seeks alliance with Thurii. Bad weather off the southern coast of Italy forces him back to Tarentum, where many of his ships must be hauled ashore and repaired (6.104.2). By the summer of 414, therefore, things look dark for Syracuse. Nikias hears of Gylippos' approach but scorns (hupereide) the small number of ships and infers that his only purpose with such a small force can be piracy. Syracuse is on the brink of capitulating to Athens.

55 As book 7 opens, however, Gylippos receives more correct - and favorable - information from Syracuse. The Athenian wall is incomplete, and Syracuse is not fully besieged. His army can still arrive by the Epipolae and enter the city to defend it. Sailing to Himera, on the north coast of Sicily, he allies with Himerians, Selinounians, and others. Hence he sails for Syracuse with a significant force: 700 sailors and armed marines, a thousand hoplites and light troops from Himera, and additional forces from the other polei (7.1.5). According to Thucydides, the power of Gylippos is his enthusiasm (prothumos). A Corinthian fleet, commanded by Gongylus, reaches Syracuse in the nick of time. Gongylus reports to the Syracusans that Gylippos is on his way. Reassured, they abandon thoughts of capitulation.

56 This is the first turning point in the Sicilian campaign. The Syracusans gain courage (eperrosthesan) and march to meet Gylippos. He arrives as the Athenians push to complete their wall. His sudden approach of Gylippos confuses (ethorubethesan) the Athenians at first. He sends a herald to offer the Athenians five days to evacuate. They disdain the offer - treating it "lightly," with contempt (oligoriai) - and do not bother to respond. Disorder (tarassomenos, to be stirred up, troubled, confounded) among Syracusan troops keeps Gylippos from attacking. Still Nikias' fatal flaw, his inactivity (hesuchaze), leaves the advantage unseized.

57 Once the Syracuse cavalry, under the leadership of Gylippos, does come into battle, momentum shifts quickly shifts to the Syracusans. They extend their counter-wall past the Athenian wall. Corinthian and allied ships aid Syracuse, and Gylippos brings other Sicilian cities its cause. He sends back to Sparta and Corinth for reinforcements. Syracuse evens plans to challenge 
Athenians on the sea, where they had been thought invincible. In short, Syracusans become greatly encouraged (polu eperronto) (7.7.4).

\section{Nikias' Letter to Athens}

58 Nikias recognizes that Gylippos and his additional forces are putting the Athenians into a grave situation. Nikias sees the daily increase in ischun of his enemy and knows his own aporian (7.8.1). Toward summer's end in 414, he asks Athens for massive reinforcements. He concedes that Athenians have been forced to halt work on their wall and "to remain inactive" (hesuchazomen) save to defend it (7.11.3). The counter-wall must be taken before the city can be attacked. Thus "we who seemed to besiege others are besieged ourselves" (7.11.4, Hobbes).

59 Long at sea, the Athenian fleet is eroding. Ships are rotting, and crews are "wasted." The Athenians cannot drag ships ashore for drying, because they must stay ready for battle in a hostile region where larger numbers of quality ships oppose them. When not cut off by the Syracusan cavalry, they must travel far on land for water, fuel, and forage. Athenian morale declines. Some slaves defect, leaving more work for the sailors and soldiers. Foreign troops are "impressed by the unexpected appearance of a navy against us, and the strength of the enemy's resistance" (7.13.2, Crawley). This leads troops pressed into service to depart for their home polei at the earliest opportunity. The resistance of Sicily exceeds their expectations. Initiative passes to the enemy (7.12.5).

60 Given the changed balance of forces, Nikias asks Athens to recall the expedition or reinforce it with a contingent equal the one already there. Nikias also asks that he be relieved, because a kidney ailment leaves him unfit to command (7.15). The Athenians do not accept his resignation, but they do send significant reinforcements led by Demosthenes, architect of the Pylos strategy, and Eurymedon. J ust as Nikias had warned when debating the expedition, though, Sparta attacks Athens. As Alkibiades advised, moreover, Sparta fortifies Decelea, a mere 1314 miles from the Athenian polis. Athens now faces war on two fronts.

\section{Syracusan Audacity}

61 When Gylippos returns with the forces from other Sicilian cities, he calls on Syracuse to prepare for a sea fight. Gylippos and 
Hermokrates, his ally among the Syracusan leaders, seek to persuade Syracusans that the Athenian navy is not invincible. Audacity could break the spirit of the Athenians. To courageous (tolmerous) men such as the Athenians, a courageous attack can appear most formidable. The Athenians strike fear (kataphobousi) into their neighbors with bold attacks; now this can be done to them. To attack Athenians at sea would be unexpectedly bold (tolmesai aprosdoketos), putting fear into them (ekplagenton). The resulting advantage in morale would outweigh whatever material damage the Athenians might inflict (7.21.3-4).

62 The battle's outcome is mixed: Syracuse loses eleven ships and many men in its harbor, as against three ships for Athens. On land, however, the Syracusans take three forts in Plemmyrium, to the south of the great harbor, which are vital as warehouses for the Athenians. Syracusans capture large stocks of Athenian goods and grain along with equipment for forty triremes. In the telling of Thucydides, this is a significant tactical defeat for Athens. It loses materiel; and with Syracusan ships at the harbor entrances, it must fight to provision its troops. But more important is the shift in momentum. The Athenian forces become terrified (kataplexin) and demoralized (athumian) (7.24.3). In Attica, the fortification of Decelea makes a long occupation possible. Spartan troops become "permanently fixed in Attica," causing great destruction, and forcing the Athenians to rely even more on imports. Worst of all, the Athenians are saddled with "two wars at once" (7.27-28).

63 In Sicily, with the tide turning against the Athenians, the other cities come one by one to the assistance of Syracuse. As this bandwagon allies additional forces against the Athenians, Syracuse plans another land-and-sea attack. It reinforces the prows of its triremes to ram Athenian ships more effectively. Syracuse controls most of the harbor's shore, so the Athenians are limited in backing up (7.36.5). They are alarmed (ethorubounto) to see Gylippos attacking by land and sea simultaneously. After several days, the Syracusans win a minor victory. With an assured expectation (elpida) of superiority at sea and strength on land, they prepare further attacks (7.41.4).

\section{Demosthenes' Night Attack}

64 At this moment, Demosthenes and Eurymedon arrive from Athens with 73 ships and almost 5,000 troops, many hoplites. This massive force dismays (kataplexis) the Syracusans, who worry for a moment that there might be "no end to their dangers." They had 
expected the fortification of Decelea to draw Athenians away from Sicily; instead Athens has reinforced its expedition with a force almost equal to the initial invasion. Athenians regain strength (hrome) amidst their troubles (7.42.2). Demosthenes sees that the Nikias' move to winter in Katana instead of attacking further had "allowed the terror of his first arrival to evaporate in contempt" (Crawley). Demosthenes determines to strike immediately. This would win Syracuse with a bold stroke or enable Athens to withdraw its entire force with the least waste of lives (7.42.3-5).

65 After failing to besiege the city in daylight, Demosthenes plans a night battle, an act of unexpected audacity (adoketou tou tolmeatos) (7.43.6). It is the only night battle of the war. Initially the Athenians succeed, but their advance succumbs to increasing disorder. War chants of Athenian allies resemble those of Syracusans, confusing the Athenians, making them aporian. According to Thucydides, the situation becomes chaotic and terrifying for the Athenians (7.44.4-5). In the end, they fight not only the Syracusans but also many Athenian allies. "As they fled before the enemy, the way of the descent from Epipolae by which they were to go back being but strait, many of them threw themselves down from the rocks, and died so" (7.44.7-8, Hobbes).

66 The audacious move of Demosthenes ends in defeat. The Syracusans win an important victory. The unexpected good fortune (aprosdoketoi eupragiai) restores their former courage, confidence, anarrosthentes (7.46.1). The disaster (sumphoran) leads Demosthenes to advocate immediate withdrawal. The army has failed. The soldiers are aggrieved, vexed, achthomenous. Disease sets in as they camp on marshy ground. Everything appears hopeless (anelpista) (7.47.1-2). Demosthenes favors an active, consolidated defense. Athenians should abandon the Sicilian campaign, return to Athens, and wage a concentrated struggle against the Spartan forces ravaging the Attic countryside. In short, they should return to the policy of Perikles.

67 Nikias estimates the situation differently. He acknowledges Athenian troubles in Sicily, but he thinks Syracusans stumble too. Naval superiority provided by the new ships means that an effective blockade could be maintained, and a pro-Athenian faction in the city is scheming to betray Syracuse. It would soon be ruined by costs of the blockade. Furthermore Nikias fears the harsh judgment of his own leadership if Athenians return now to Athens (7.48-49). He even opposes Demosthenes' call to move the land forces to more favorable ground. But Gylippos returns to Syracuse 
with new reinforcements from other Sicilian cities and more hoplites from the Peloponnesus. Athenian soldiers grow worse from illness. Finally Nikias relents and agrees to leave. Yet an eclipse of the moon concerns the Athenians, who urge their generals to hesitate before this divine sign (7.50).

68 Full of energy and confidence, Syracuse again attacks the Athenians by land and sea. When it wins decisively at sea, in the harbor, even against the fleet reinforced by Demosthenes, the Athenians are athumias, "utterly out of heart" (Hobbes). Deceived (paralogos) by events, they regret (metamelos) the expedition (7.55.1). Already perplexed (eporoun), they have now lost at sea, where it was least expected (7.55.2). Victory elates Syracuse, since it has defeated Athenians on the water, where they had been thought invincible. The confidence of Syracuse soars so high that it establishes new goals for the engagement. It now wants to close the harbor so that the Athenians cannot escape (7.59.3).

69 Desperate Athenians attempt several times to break out. But "unprecedented and decided defeat at sea" disheartens (athumoutas) them (7.60.5). For Thucydides, Syracuse succeeds both because it gains material advantage over the Athenians and because the Athenians lose heart. As Gylippos puts it, "When men are once checked in what they consider their special excellence, their whole opinion of themselves suffers more than if they had not at first believed in their superiority, the unexpected shock to their pride causing them to give way more than their real strength warrants; and this is probably now the case with the Athenians" (7.66.3, Crawley).

\section{"The Greatest Reversal"}

70 The Athenians fail to escape the harbor. Their soldiers on land, observing the great battle in the harbor, are "prey to the most agonizing and conflicting emotions" (7.71.2). When events at sea turn against Athens, its soldiers panic (ekplexis). Loss of the fleet threatens not only their lives and safety but the safety of their home polis as well. In defeat, even the Athenian sailors are so utterly overcome (katapelechthai) that they refuse to board their ships. They no longer believe in the possibility of success.

Defeatism consumes the sailors of the greatest Hellenic sea power (7.72.3).

71 The final episode of the tragedy is the attempt by Nikias and Demosthenes to lead the Athenians away on land. All ships lost, 
all hopes and expectations ( megales elpidos) dashed, the Athenians disintegrate. They leave their dead unburied, a sacrilege. They abandon the sick and seriously wounded. "Insomuch as the whole army, filled with tears and irresolute, could hardly get away, though the place were hostile and they had suffered already, and feared to suffer in the future, more than with tears could be expressed; but hung down their heads and generally blamed themselves" (7.75.2-4, Hobbes). Demoralized (aporian), disgraced, humiliated, forty thousand Athenians and allies march out, soon to surrender. Comparable to a "starved out polis," they fall to dejection and self-condemnation for their failure. Nikias, a man Thucydides judged "of all the Hellenes in my time, least deserv[ing] such a fate," is killed (7.86.5). Thousands of Athenians become prisoners in quarries, where many perish. In Sicily, Athenians meet with an utter destruction (panolethria).

\section{The Priority of Mood for Strategy}

72 Individuals and collectivities are thrown into situations not of their own choosing. To form goals and plans, they assess their situations. They ponder: How are we doing? Are we in any danger? Should we feel confident? Should we feel safe? As people ask and answer, their faculties of reasoning and feeling are fully in play. To make and evaluate plans, people tap moods of confidence, fear, fatigue, panic, ambition, and more. In the world of Thucydides, the speakers, deliberators, and doers succeed through attunement to moods. These people recognize moods, mobilize them, inform them, contest them, and learn from them. Moods color assessments, but precise estimations of their character or effect can be difficult. For most people, moods come to clear consciousness only in part, even as they figure prominently and appropriately in reasoning. Rare are the leaders who measure acutely the significance of moods for themselves or others.

73 Strategic leaders especially should respect communal moods. Material assessments of situations must count moods as important. The arrogance, complacency, urgency, or anxiety of a group can change events in war, politics, and more. Otherwise superior but demoralized strength seldom prevails. Strategic leaders must counteract collective moods at odds with their settings or plans. Factional infighting or overdone backslapping can sap the ability of any group to succeed.

74 The moods of strategic leaders can affect, even infect, their 
followers. Doubt or undue confidence can cripple a group by gripping one of its leaders, just as surely as fear or arrogance can impede the group by suffusing its ordinary members.

75 Even the vaunted individualism of Americans - and their rational choice theories - is more a matter of mood than of biology or liberty. Only when a mood of narrowly selfish self-regard pervades a situation does it operate like the economist's market. In the fractious Greece of Thucydides, that family of moods was not unknown, but neither was it predominant.

76 There are implications for methods of social science. Models of rational choice embed assumptions about collective moods. A sense of solidarity dissolves the prisoners' dilemma. So gangs, movements, and institutions cultivate solidarity. It is the infection of such groups by a mood of individualism that brings the possibility of free riding; and any "rational calculation" by individuals must involve self-interrogation about confidence, trust, and other aspects of mood. How much confidence do individuals have that their confederates will not ride free? As Thucydides suggested, divided and demoralized groups are the ones that can be sure that it is every man for himself. Members in a different mood, confident that colleagues or comrades have their backs, act less often as individualists.

77 Like political strategies in the tales of Thucydides, rational calculations in the mode of Mancur Olson predicate reasoning on moods. ${ }^{29}$ Moods inform rational judgments. Collective moods are thus an element of practical reasoning. Political language that separates reason and realism from moods is at best an artificial simplification. Real strategic actors do - and should - think (in part) with their hearts. Using their heads, successful political performers take into account their own hearts and those of others. Consider the importance of anger at injustice as a ground for rational action, or the significance of dismay as a basis for reasoned inaction. If we dismiss anger, dismay, or other moods as legitimate considerations in what we do, we fail a strategic test for political success apparent in the narratives of Thucydides.

78 Dramatists often simplify the action. "Usually some one character ... enjoys the role of primus inter pares." This character is the "summarizing vessel" of "the development as a whole." 30 In the writing of Thucydides, this representative character is Athens. It is managed well by the great statesman, Perikles; but after his death, its impetuous action leads to tragedy. Goaded by violent, 
vindictive politicians like Kleon, Athens nearly commits in the Mytilene case a fatal error of excess. Even with the good fortune of the Pylos episode, Athens fails to make peace. Again driven by advice from Kleon, Athens reaches out for more than it deserves. After Kleon dies, a bloodlessly cruel Athens eradicates the island population of Melos. Hubristic passion trumps polis advantage. The disaster skirted in Mytilene now comes to a cold conclusion. In a spirit of hubris, Athens immediately mounts an extreme expedition to dominate its Peloponnesian enemies by seizing Syracuse and the rest of Sicily. During this overextension, Alkibiades and Nikias struggle over the soul of Athens. Neither has the stature or skill of Perikles, and each suffers a fatal weakness. Together these produce the Sicilian tragedy.

79 Throughout the account of Thucydides, Athens is like a fine gyroscope. When working effectively, under able leadership, it acts within appropriate limits and attains success through its distinctive excellence: the fleet. After Perikles, no leaders keep Athens within its compass. After Kleon and Alkibiades drive it into trouble, Diodotos and Demosthenes revive the Periklean legacy, but only momentarily. Nikias fails to persuade the assembly to hold back; and when in Sicily, his inactivity furthers the decline of Athens.

80 In the telling of Thucydides, this tragedy involves many moods for Athens. Perikles must revive spirits when invasion and plague costs Athenians confidence after only two years of war. Diodotus must dampen their viciousness in Mytilene case. After Pylos, Kleon manipulates Athenian pleonektë̈. In facing Melos, the mood of Athenians is calculating and brutal. In turning to Sicily, it becomes passionate grasping. The overall trajectory of Athens is toward excess. For Thucydides, the figure who personifies this mood is Alkibiades, the brilliant rhetor and general who lives beyond his own means and whose excesses seduce the polis. Where Perikles stands incorruptibly above suspicion, Alkibiades lurks in shadows and proves quick to betray Athens. Where Perikles puts the polis before personal benefit, Alkibiades subordinates Athens to his own gain and glory. When Athens no longer serves these selfish desires, Alkibiades quickly abandons it for the enemy. Already the damage has been done, though, with Athens already seduced into dangerous overextension. ${ }^{31}$

(C) Glenn Perusek, 2004. 


\section{Notes}

1 As J . de Romilly writes in Thucydide et l'impérialisme athénien on p. 97, "Il ne se contente pas de reproduire les faits: il choisit, il pense, il construit; c'est une realité élaborée qu'il nous présente, et, par là même, soumise à son jugement." Cited in H. D. F. Kitto, Poiesis, Berkeley, University of California Press, 1966, p. 259.

2 David Grene in Thucydides, The Peloponnesian War: The Complete Hobbes Translation, Chicago, University of Chicago Press, 1989, p. 480n. J. B. Bury, A History of Greece, New York, Modern Library, 1937, p. 431, makes much the same point in his overview history of Greece: "In Grecian history we must steadfastly keep in view that we are reading about citizen soldiers, not about professional soldiers; and that the temper of the time, whether of confidence or dismay, modifies all the calculations of military and political prudence." Throughout this essay, I have made regular use of three translations of Thucydides' text: in addition to the Hobbes translation, I have used The Landmark Thucydides, Robert B. Strassler, ed., Richard Crawley, tr., New York, Simon and Schuster, 1998, a well-known nineteenth century translation; and Thucydides, The Peloponnesian War, Steven Lattimore, tr., Indianapolis, Hackett, 1998, a careful latetwentieth-century work.

3 Francis M. Cornford, Thucydides Mythistoricus, Philadelphia, University of Pennsylvania Press, (1907), 1971, pp. ix-x: "Thucydides possessed, in common with his contemporaries at Athens, the cast of mind induced by an early education consisting almost exclusively in the study of the poets. No amount of hard, rational thinking . . . could suffice to break up this mould."

4 Plato, Republic, 496c.

5 Ibid., 433a.

6 See G. M. A. Grube, Plato's Thought, Indianapolis, Hackett, 1980, p. 136.

7 Plato, Republic, 580d-581c.

8 Grube, Plato's Thought, p. 136; Plato, Symposium, 202.

$9 \quad$ Ibid., 210 and 211. 
11 Aeschylus, Agamemnon, 338f.

12 Aeschylus, Prometheus Bound, 1054 and 982.

13 Aeschylus, Persians, 808.

14 Aeschylus, Persians, 807-831, especially 808, 821, and 829.

15 Plutarch, Perikles, 20, in Cornford, Thucydides Mythistoricus, p. 44. And "The Athenians were coveting Sicily while Pericles was still alive, and after his death they attacked her and sent their socalled relief expeditions to prepare the way for the great expedition against Syracuse" (Alkibiades, 17, in Cornford, Thucydides Mythistoricus, p. 44).

16 Every other use of kataphronesis in Thucydides, save one, is negative, in keeping with the translation, "arrogance" or "contempt. At 1.22.4, the Corinthians close a speech to their allies opposed to Athens warning them not to take refuge in the arrogance that leads to disaster, an arrogance that fosters negligence, foolishness or lack of courage. At 2.11.4-5, Archidamus counsels a fearful apprehensiveness as the basis for great, careful preparations. Kataphronesis leads to a lack of preparation, and can therefore lead to defeat. Courage based upon knowledge, leading to preparation in practice, will result in the army being best spirited and safest. Similarly, in Herodotus, Darius says the Scythians "despise us utterly" (4.134; Herodotus, The Histories, David Grene, tr., Chicago, University of Chicago Press, 1985). In Plato, Apology, 28c, Achilles is "contemptuous of danger" (see G. M. A. Grube's translation in Plato, Complete Works, J ohn M. Cooper, ed., Indianapolis, Hackett, 1997). In the Republic, 556d, the poor are "despised" by the rich.

17 Hobbes, as usual, translates directly and strongly: "Therefore, whensoever he saw them out of season insolently bold, he would with his orations put them into a fear; and again, when they were afraid without reason, he would likewise erect their spirits and embolden them."

18 Expectation, elpis, also appears at 3.97, where good fortune at meeting no opposition leads to hopeful good expectation for success, and at 4.71.

19 Demosthenes' capability as a general is demonstrated by his 
twofold relation to Perikles. On the one hand, he readily reverses the elpis-gnome order. But in doing so, in his exhortation to the defenders of Pylos, he immediately emphasizes the importance of the single, central factor, the decisive factor - the terrain will allow only small detachments of Spartans to attack at a time - recalling Perikles' emphasis on the single insurmountable Athenian advantage - in that case, naval superiority.

20 As Cornford, Thucydides Mythistoricus, notes, the ancient critic, Dionysus of Halicarnassus, saw the Athenian language as "fit only for an oriental monarch." A Greek could speak thus only under the condition "that the speaker be mad." Cornford, p. 182, continues: "as we read the dialogue, the impression deepens that the Athenian spokesman is out of his right mind. We can, moreover, put a name to the special form of his madness, which shows the peculiar symptoms of a state classed, perhaps rightly, by the Greeks as pathological. The two notes of it are Insolence (hubris) and Blindness ([ate], in the subjective sense)."

21 Thucydides' introduction to the speech of Alkibiades, 6.15, may be "notably complex" (Lattimore, p. 314n), "controversial" (K. J . Dover, ed., Thucydides, Book VI, Oxford, Clarendon Press, 1965, p. 23) or simply contradictory.

22 From kathairein, which Dover, 1965, p. 24, suggests "is a very strong word, used elsewhere of final and decisive defeat." See 5.103.1. Dover opines that this word is too strong for the result of the Sicilian campaign, and also could not have been written shortly after 413, as Thucydides recognized that Athens recovered from the massive but not decisive defeat of Sicily.

23 Homer, Iliad, 14.92; Odyssey, 4.730.

24 Homer, Iliad, 5.60. See also Aeschylus, Prometheus, 982;

Agamemnon, 962; Sophocles, Oedipus Tyrannus, 589.

25 Heraklitus, fr. 57.

26 Grene's translation, 1985, p. 268.

27 Shakespeare, Macbeth, Act IV, Sc. 1. The Apparition says that "none of woman born shall harm Macbeth," and that "Macbeth shall never vanquish'd be, until Great Birnam wood to high Dunsinane hill shall come against him." Macbeth exclaims with enthusiastic confidence, "Then live, Macduff: what need I fear of thee?" and "That will never be." In Herodotus, see also 1.122, 
where parents have sure knowledge (epistamenoi) that their son had been dead. See also 2.3. The distinction of gignosko and epistamai had to have been well-ingrained in the Hellenistic world, for in Acts 19.15, the spirit says to the J ewish exorcists, "J esus I know (gignosko) and Paul I know (epistamai), but who are you?"

28 Lattimore and Crawley both translate gnome as "spirit." The mind of Syracuse is the spirit or the courage of the polis.

29 See Mancur Olson, The Logic of Collective Action, New York, Schocken Books, 1965.

30 Kenneth Burke, A Grammar of Motives, Berkeley, University of California Press, 1945, p. 516.

31 As I have developed the ideas in this paper, I have benefited from comments of Michael Bastian, J org Baumgartner, Nancy Forsythe, Libby Garland, Andrew Grossman, Adam Lutzker, Guy Oakes, and J eff White. Two anonymous reviewers from Poroi also provided valuable suggestions. I owe Andrew Dinan a special thanks for his generous willingness to work with me on translations. I have also learned a great deal from J ohn Nelson and the participants in the yearly Foundations Workshop on Political Myth, Rhetoric, and Symbolism. 